\title{
sciendo
}

\section{Personal Income Taxation Determinants in Federation of Bosnia and Herzegovina}

\author{
Irena Palić \\ Faculty of Economics and Business, University of Zagreb, Zagreb, Croatia \\ Sabina Hodžić \\ Faculty of Tourism and Hospitality Management, University of Rijeka, Rijeka, \\ Croatia \\ Ksenija Dumičić \\ Faculty of Economics and Business, University of Zagreb, Zagreb, Croatia
}

\section{Abstract}

Background: In recent years' income inequality has been an economic issue. The primary instrument for redistributing income is personal income tax. However, based on economic theory income inequality concerns indicators such as wages, transfer payments, taxes, social security contributions, and geographical mobility. Objectives: The objective of this paper is to examine the impact of certain labor market indicators on personal income taxation in Federation of Bosnia and Herzegovina (FB\&H). Methods/Approach: Since personal income taxation consists of a very broad definition and for the purpose of this research only, income from dependent (employment) activity is observed. The econometric analysis is conducted using error correction modeling, as well as forecast errors variance decomposition. Results: The error correction model is estimated, and the cointegrating equation indicates that monthly wage and number of employees statistically significantly positively affect personal income taxes in FB\&H in the long-run. After two years, the selected labor market indicators explain a considerable part of forecasting error variance of personal income tax revenues. Conclusions: The implementation of reforms in the labor market and tax policies of the FB\&H is suggested. In order to achieve necessary reforms, efficient governance and general stable political environment are required.

Keywords: error correction model, Federation of Bosnia and Herzegovina, labor market indicators, personal income taxation

JEL classification: C22, C51, H24, H71

Paper type: Research article

Received: Sep 03, 2018

Accepted: Jan 03, 2019

Citation: Palić, I., Hodžić, S., Dumičić, K. (2019), "Personal Income Taxation Determinants in Federation of Bosnia and Herzegovina" Business Systems Research, Vol. 10 No. 1, pp.153-163.

DOI: 10.2478/bsrj-2019-0011

Acknowledgments: This work has been fully supported by Croatian Science Foundation under the project STatistical Modelling for REspoNse to Crisis and Economic GrowTH in WeStern Balkan Countries -STRENGTHS (HRZZ-IP-2013-11-9402) 


\section{Introduction}

A major instrument in achieving economic policy goals in all governments is a tax policy. Moreover, the majority of public revenues in the state budget is collected from taxes. During World War II, income taxation grew in importance (Pechman, 1987). Nowadays, in public finance theory, there are two types of worldwide income taxation. According to Rosen and Gayer (2008), these are the global and territorial systems. In the first one, the tax authority of the country of citizenship puts the tax on the worldwide income of an individual, while in the second one, citizens who earn income abroad are taxpayers only in the country where the income has been made.

In order to achieve an efficient distribution of income, governments often use progressive taxation. In a case of income inequality, the main determinants that are examined are wages, transfer payments, and social security contributions. Federation of Bosnia and Herzegovina (FB\&H) and Republic of Srpska (RS) are two entities of Bosnia and Herzegovina (B\&H). The structure of FB\&H consists of 10 cantons, inside which are 79 municipalities and the RS does not have cantons, only 62 municipalities. Based on their economic situations, there is a mismatch between these two entities in the taxation of labor. In most cases, this leads to confusion and problems for foreign investors as well as the tax burden of companies. The personal income tax in FB\&H was adopted in 2008 and came into effect on 1 January 2009. This tax simplified the income tax system by replacing 60 cantonal taxes with a single tax (Sahinagic et al. 2005). The tax rate is 10 percent, flat and the taxable income is the difference between the total gross income received and deductibles in one tax period. According to the Law on Personal Income Tax in FB\&H (Tax Administration of the Federation of Bosnia and Herzegovina, 2018), income consists of five sources. These are income from dependent (employment) activity (wages, compensations and other income earned from dependent activity), income from independent activity (income earned from entrepreneurial, agricultural, and forestry activities, temporary activities, and other independent activities), income from property and property rights, income from investment in capital, and income from contests and games of chance. Therefore, personal income is the total gross income received by the taxpayer in a tax period, only with the exception of income not considered as taxable income and income exemptions. A person who is obligated to pay tax or taxpayer is a resident of $\mathrm{FB} \& \mathrm{H}$ regardless of whether the income is received in $\mathrm{FB} \& \mathrm{H}$ or worldwide, and a non-resident who receives income in FB\&H.

All neighboring countries, like Croatia and Slovenia, have been going through the reform process in the taxation of personal income tax. In $\mathrm{B} \& \mathrm{H}$, the first reform was introduced in 2006. Therefore, reformed Personal Income Tax Law was in effect from 2007 in RS, while only from 2009 in FB\&H. From 2009, FB\&H introduced the comprehensive personal income tax and was faced with a scheduler system (Sahinagic et al. 2005). Antic (2013) concluded that after the reform of indirect taxation in $\mathrm{B} \& \mathrm{H}$, the considerable part of the revenues leads to an increase in governments' fiscal autonomy.

Taxes have different functions such as collecting revenues to fund government services, to correct market imperfections, to distribute the cost of government in an efficient way and to change the distribution of income. Besides taxes, labor market indicators such as wages, transfer payments, social security contributions, etc. also have an impact on the distribution of income. Through this research, we attempt to contribute to the evidence of the impact of certain labor market indicators on personal income taxation in FB\&H. The following research question is posed: What is the impact of certain labor market indicators on personal income taxation in $\mathrm{FB} \& \mathrm{H}$ ? 
Following other research and economic theory discussed in the next chapter, the research hypothesis is that certain labor market indicators have a statistically significant positive impact on personal income taxation. For the purpose of this research and due to reliable data availability, only income from dependent (employment) activity is observed. To obtain empirical results and to assess the stated research hypothesis, the error correction modeling, as well as forecast errors variance decomposition have been used. The paper is organized in the following way. After the introduction, section two briefly describes the literature on the determinants and problems within personal income taxation. The third section presents data and methodology while section four the main empirical results and discussion.

\section{Literature Review}

In the literature, various studies analyze income inequality and personal income taxation from transition countries and beyond. Therefore, Bird et al. (2005) examined the re-distributive role of personal income taxation. Based on their research, in developed countries, the income redistribution is more strongly affected by personal income taxation in relation to developing countries. Other authors also examined the relationship between income inequality and redistribution (Alesina et al., 1994; Perotti, 1996; Milanovic, 2000; Karabarbounis, 2011; Antonis et al., 2015; Šimurina et al., 2017a).

Following economic theory, the main objective of progressive taxation of income is to ensure efficient tax burden distribution. Therefore, governments tend to achieve social welfare and stimulate individuals to work in a more efficient way (Diamond et al., 2011). Therefore, the main task of personal income taxation is to collect tax revenues for the state budget. By observing OECD countries, Castro et al. (2014) pointed out that there are considerable differences in tax revenues determinants between more and less developed countries. Taking into consideration personal income tax, corporate income tax, and value-added tax during the financial crisis that started in 2008, Šimurina et al. (2017b) investigated the effects of tax changes in the EU-13. In the case of the United Kingdom, Ivanitskaya et al. (2013) pointed to a statistically significant positive impact of the number of taxpayers and inflation on personal income taxation. In Croatia, a neighboring country of $\mathrm{B} \& \mathrm{H}$, a few researchers examined the determinants of personal income taxation (Urban, 2006; Palić et al., 2017a) while others examined income inequality (Nestić, 2002; Sever et al. 2003; Obadić et al., 2014). Therefore, Palić et al. (2017a) found that in Croatia there is "significant negative impact of economic conditions and the statistically significant positive impact of average monthly wage and number of taxpayers on personal income taxation in the long run" (p. 12). Between 1973-1998 in Croatia, income inequality did not change considerably, which can be explained by increased social transfers and the fact that wages did not increase significantly (Nestić, 2002).

The literature on inequality determinants is scarce in transition countries (Milanovic, 1999; Keane et al., 2002; Mitra et al., 2006; Giammatteo, 2006; Koeninger et al., 2007).

Mitra et al. (2006) examined the main elements of income inequality in developing countries. They observed liberalization of capital, goods and services and privatization of state-owned enterprises. They found that EU-13 countries have a slower and more gradual increase, while republics of the former Soviet Union have a rapid increase in inequality. However, Koeninger et al. (2007) found that wage inequality is caused by inefficient labor market institutions and their policies. Obadić et al. (2014) on a sample of fifteen European Union members and thirteen Central and Eastern European economies concluded that income inequality is decreased by adequate social security contributions and labor taxes. To obtain empirical results, they used panel models for the period 2000-2011. 
Concerning the $\mathrm{B} \& \mathrm{H}$, there is no similar research. Antic (2013) focused more on fiscal decentralization in $\mathrm{B} \& \mathrm{H}$ and Kramer (2016) on the alternative personal income tax system. Since B\&H has a very complex fiscal system, this research fills the gap with an empirical analysis of labor market indicators on personal income taxation in FB\&H.

\section{Data and Method}

In order to obtain results, data from the Federal Office of Statistics (2017) and Federal Ministry of Finance of FB\&H (2017) is collected on a monthly basis from 2012 to 2016 in the convertible mark (KM). In line with the research of Palić et al. (2017a) for Croatia, the following variables for FB\&H are included in the analysis: personal income tax revenues, net wages, number of employed persons, consumer price indices and industrial production indices. The monthly data from January 2012 to December 2016 is used in cointegration analysis. Data on personal income tax revenues are collected from the Federal Ministry of Finance of FB\&H (2017). Data on net wages, number of employees, consumer price indices and indices of industrial production is available at the Federal Office of Statistics of FB\&H (2017). The nominal personal income tax revenues and net wages are deflated using consumer price indices, 2010=100 available at Federal Office of Statistics of FB\&H (2017). The three variables used in the further analysis are deflated values of personal income tax revenues (t) in $K M$, net wages ( $W$ ) in KM and number of employed persons (n). The descriptive statistical measures of selected variables are given in Table 1. The coefficient of variation points to low variation in wages, moderate variation in personal income taxes and quite a high variation in a number of employed persons.

Table 1

Descriptive Statistics of Selected Variables

\begin{tabular}{lrrr}
\hline Descriptive statistics & $\boldsymbol{\dagger}$ & $\mathrm{w}$ & $\mathrm{n}$ \\
\hline Mean & 21862194 & 797.54 & 354891.14 \\
Median & 21085334 & 795.52 & 437667.50 \\
Standard Deviation & 4113046 & 14.27 & 178919.93 \\
Coefficient of variation & 18.81 & 1.79 & 50.42 \\
Kurtosis & 3.20 & 0.56 & 0.37 \\
Skewness & 0.12 & 0.60 & -1.53 \\
Range & 26924293 & 68.34 & 463285.21 \\
Minimum & 6743601 & 770.03 & 445.79 \\
Maximum & 33667894 & 838.36 & 463731 \\
Count & 60 & 60 & 60 \\
\hline
\end{tabular}

Source: Authors' work

Prior to cointegration analysis, data is seasonally adjusted using the X-13 ARIMA seat method (see United States Census Bureau, 2017). In order to eliminate the residual heteroskedasticity problem, logarithmic transformation is used. Therefore, the following variables are defined: logarithmic seasonally adjusted deflated personal income tax revenues (It), logarithmic seasonally adjusted deflated net wages (IW) and logarithmic seasonally adjusted number of employed persons (In). In order to assess the long-run impact of selected labor market variables on personal income taxation in FB\&H, the Johansen's approach to cointegration is used. It is important to note that long-run equilibrium in econometric terms does not refer to market equilibrium, but to the long-run relationship of non-stationary variables (Palić, 2017, Palić et al., 2017b).

Vector error correction (VEC) model is given by (see Lütkepohl, 2004; Enders, 2015). 


$$
\Delta_{y_{t}}=\Pi y_{t-1}+\Gamma_{1} \Delta y_{t-1}+\cdots+\Gamma_{p-1} \Delta y_{t-p+1}+u_{t}
$$

where $\Pi=-\left(c-A_{1}-\cdots-A_{p}\right)$ and $\Gamma_{i}=-\left(A_{i+1}+\cdots+A_{p}\right)$ for $t=1, \ldots, n$ and $i=1, \ldots, p-1$. Parameters $\Gamma_{i}$ for $i=1, \ldots, \mathrm{p}-1$ are short-run parameters and $\Pi_{y_{t-1}}$ is the long-run part of the model. Johansen's procedure includes the assessment of the rank of the matrix $\Pi$. If the rank of matrix $\Pi$ is less than the number of variables in the model, matrix the is given by:

$$
\Pi=\alpha \beta^{\prime}
$$

where $a$ is a $k \times r$ matrix of error correction velocity that quantifies the velocity of variables' return to the equilibrium and $\beta$ is $k \times r$ cointegration matrix of long-run equations' parameters. The explanation of the VEC model and Johansen's procedure can be found in Lütkepohl (2004) and Enders (2015). Johansen's procedure uses eigenvalues of estimated matrix $\Pi$, namely $\widehat{\Pi}$, to determine the number of cointegration relations. After the VEC model estimation, eigenvalves of the matrix $\widehat{\Pi}$ are calculated. Matrix rank is equal to the number of eigenvalues that are different from zero. Eigenvalues of matrix $\widehat{\Pi}$ are given by:

$$
1>\hat{\lambda}_{1} \geq \hat{\lambda}_{2} \geq \ldots \geq \hat{\lambda}_{\mathrm{n}}>0
$$

in descending order. If $r$ eigenvalues are different from zero, values of $\ln \left(1-\widehat{\lambda}_{l}\right)$ will be lower than zero for all $i=1, \ldots, r$. In line with aforementioned, trace test and maximum eigenvalue test (see Enders, 2015, for explanation) are used to assess the number of cointegration relations. Both tests are conducted until the null hypothesis about number of cointegration relations cannot be rejected for the first time. When null hypothesis is rejected for the first time, the conclusion is that the number of cointegrating relations equals $r$ (Enders, 2015).

After model estimation, it is necessary to analyze the model residuals. The assumption of the error correction model is homoskedasticity, which refers to the constant variance of model residuals $u_{t}$, namely:

$$
\operatorname{Var}\left(u_{t}\right)=\sigma^{2}=\text { constant }, \forall t=1, \ldots, n
$$

The problem of heteroskedasticity is present when variances of $u_{t}$ are variable. If there is a heteroskedasticity problem, parameter estimates are unbiased and consistent, but are no longer efficient. This causes wrong calculation of the standard errors of the estimated parameter, and the significance tests of parameters cannot be performed (Maddala and Lahiri, 2009). Furthermore, the assumption of the error correction model is that the autocorrelation of residuals $u_{t}$ is not present. Residual are not autocorrelated if covariance of residuals equals zero, namely:

$$
\operatorname{Cov}\left(u_{t}, u_{t-1}\right)=0, \mathrm{t}=1, \ldots, \mathrm{n}
$$

If autocorrelation of residuals exists, the calculation of standard errors of the estimated parameters may be incorrect and tests of significance cannot be carried out (Maddala et al., 2009, Enders, 2015). 
Finally, although the cointegrating equation offers the long-run parameters, the important information about the relationship of variables is also provided by forecast errors' variance decomposition. The variance decompression shows the proportion of the variance of the prognostic error due to variations in the variable itself and other variables. In empirical research, usually variable itself explains a large proportion of variance of its prognostic error over a short period of time, while with the increase in time horizons, the share of the variance of prognostic error that the variable itself explains decreases (Enders, 2015). The variance decomposition allows analyzing the relative proportions of each of the variables in explaining variance variables in future periods.

\section{Results and Discussion}

The results of Johansen's approach in Eviews 9 are given below. Prior to cointegration testing, the model should be selected regarding the existence of deterministic components. Model in which constant exists both in the long-run model (cointegrating equation) and short-run model (vector autoregression model) is selected due to lowest values of Akaike information criteria (AIC) and Schwarz-Bayes information criteria (SBC). The lag length is equal to four, which is necessary to eliminate the problem of residual autocorrelation in the estimated model.

Furthermore, the trace test and maximum eigenvalue test are conducted, and the results are provided in Table 2. For the number of cointegrating relations $r$ equal to one, the null hypothesis cannot be rejected for the first time at 5 percent significance. Hence it can be concluded that the number of cointegrating relations $r$ is equal to one.

Table 2

Results of Trace Test and Maximum Eigenvalue Test

\begin{tabular}{llllll}
\hline $\begin{array}{l}\text { Hypothesized number } \\
\text { of cointegrating } \\
\text { equations }\end{array}$ & Eigenvalue & $\begin{array}{l}\text { Trace } \\
\text { statistic }\end{array}$ & $\begin{array}{l}\text { p-value } \\
\text { (trace } \\
\text { statistic) }\end{array}$ & $\begin{array}{l}\text { Max-eigen } \\
\text { statistic }\end{array}$ & $\begin{array}{l}\text { p-value } \\
\text { (max- } \\
\text { eigen } \\
\text { statistic) }\end{array}$ \\
\hline $0^{*}$ & & & & & \\
\hline 1 & 0.818415 & 103.8991 & 0.0000 & 93.83179 & 0.0000 \\
$\mathbf{2}$ & 0.130092 & 10.06728 & 0.2756 & 7.665216 & 0.4138 \\
\hline
\end{tabular}

Note: * denotes rejection of null hypothesis at $5 \%$ significance

Source: Authors' work

Since both tests point to the existence of one cointegrating relation among personal income tax revenues $(I t)$, real net wages $(\mathrm{IW})$, and the number of employed persons (In), the error correction model (ECM) is estimated. The following cointegration equation with standard errors in brackets is estimated:

$$
l t=39.084+2.383 l w+3.079 \ln
$$

The t-statistic of variable Iw equals 4.032, and the t-statistics of In equals 10.031. Thus, both IW and In have a positive statistically significant long-run impact on personal income taxation in FB\&H denoted by it. The error correction term (ECT) equals -1.596 with t-statistic of -12.039, which points to the statistical significance of ECT. Hence, the 
monthly correction of disequilibrium is 159.6 percent, which means that less than one month is necessary for it to converge to long-run equilibrium. Therefore, this empirical analysis of labor market indicators on personal income taxation fills the gap in the literature of FB\&H. Similar research was conducted for Croatia by Palić et al., 2017a and authors conclude that average monthly wage and number of taxpayers statistically significantly increase the personal income taxes.

After model estimation, a residual diagnostics test is conducted using EViews 9. The LM test of residual autocorrelation indicates that the null hypothesis of no autocorrelation cannot be rejected up to lag $k=24$ at $5 \%$ significance. The null hypothesis of White heteroskedasticity test states that the problem of residual heteroskedasticity is not present. Since White test chi-square statistic equals 171.59 with a p-value of 0.1860 , the null hypothesis cannot be rejected at any reasonable statistical significance level. Hence, the error correction model residual diagnostic tests indicate that the stated model is adequate. The stability of the model is examined using the inverse roots of AR polynomial calculated in EViews 9. The ECM specification imposes two unit roots. In line with Lütkepohl (2005), the error correction model with $k$ variables and $r$ cointegration relation is stable if $k$-r roots are equal to one and other roots have modulus lower than one. Since there are three variables and one cointegration relation, the estimated ECM with two unit roots satisfies the mentioned stability condition.

After the exposition of the long-run equation, variance decomposition of estimated ECM is analyzed. Table 3 shows the decomposition of the variance of the forecasting error of personal income tax revenues $(I t)$, namely the percent of the forecasting error variance of it explained by each variable in ECM. The variable It itself explains 100 percent of the variation of its prognostic error in the following month. After six months, the percentage decreases to 73.74 percent, while after one year it is decreased to 57.01 percent. After two years it explains 46.13 percent of its forecasting error. Variables IW and In do not affect the variation of the forecasting error in it after one month. After six months Iw explains 23.91 percent of the forecast error variance in it, and In explains 2.33 percent of that variance. With the increase in the time period, both percentages for I $\mathrm{W}$ and In increase. Namely, after one-year IW explains 35.83 percent of the variance in it, while In explains 7.15 percent. After two years, I w explains 41.20 percent and In explains 12.67 percent of the variance in it.

Table 3

Variance Decomposition of Personal Income Tax Revenues (It)

\begin{tabular}{lllll}
\hline Month & Standard error & It & Iw & In \\
\hline $\mathbf{1}$ & 0.041250 & 100.0000 & 0.000000 & 0.000000 \\
$\mathbf{2}$ & 0.045615 & 97.48417 & 2.330589 & 0.185237 \\
$\mathbf{3}$ & 0.045965 & 96.74022 & 2.295670 & 0.964113 \\
$\mathbf{4}$ & 0.052825 & 74.98110 & 24.28819 & 0.730716 \\
$\mathbf{5}$ & 0.052932 & 74.84438 & 24.19196 & 0.963656 \\
$\mathbf{6}$ & 0.053439 & 73.74474 & 23.91871 & 2.336553 \\
$\mathbf{1 2}$ & 0.063140 & 57.01426 & 35.83920 & 7.146542 \\
$\mathbf{1 8}$ & 0.069618 & 50.46855 & 39.01944 & 10.51201 \\
$\mathbf{2 4}$ & 0.075361 & 46.12975 & 41.20331 & 12.66694 \\
\hline
\end{tabular}

Source: Authors' work

The variance decomposition results point to the conclusion that, over time, real net wages (Iw) and the number of employed persons (In) explain higher percent of the variation in personal income tax revenues $(l t)$. Wages explain the even higher 
percentage of variation than the number of employed persons, what can be explained by the fact that some employed persons with very low income are not included in personal income tax and do not even pay personal income tax. It is interesting to note that FB\&H with a single personal income tax rate of 10 percent still has a high burden on labor. This can be explained by social security contributions (SSC). In RS, SSC is collected from the employees, while in FB\&H some SSC are also collected from the employers. The analysis of International Monetary Fund (2015) outlines that the share of direct taxes in total revenues of B\&H in 2013 equals 8 percent, out of which personal income tax accounts for two thirds (p. 11). Although the personal income tax rate is low, the FB\&H is faced with a high tax burden on labor (International Monetary Fund, 2015). Regarding the labour market, not only income taxation but the total cost for employers is important (Paturot, 2017). The labor tax wedge, which is the difference between what the employee receives as compensation for the work and the total amount that the employer sets aside for the employee, can also account for a high share of labor costs and therefore affect decisions to employ workers (Paturot, 2017). International Monetary Fund (2015) outlines that the labour tax wedge is also high and differs between entities.

In addition, most discussions about the high burden on labor focus on personal income tax. For example, Chu et al. (2000) pointed to higher income inequality in developed countries in relation to developing countries. Bovenberg (2003) outlined that minimum wages, wage unions and unemployment payments are important for the relationship between taxation and labor market performance. Similar research was done by Obadić et al. (2014) but on a sample of European Union countries in the period 2000-2011 by applying panel model. They concluded that income inequality is decreased by social security contributions and labor taxes. Finally, the assessment of personal income tax determinants is important since the effect of taxation on economic growth has been a widely researched topic. Ever since the formulation of the endogenous model, the impact of taxation on economic growth is interesting both for scientists and economic policymakers. For example, Palić et al. (2017b) found that an increase in personal income taxation in Croatia statistically significantly decreases economic growth.

\section{Conclusion}

The taxation system has a huge role as a component of government revenues. The efficiency of revenue collection into budget depends on various factors such as the complex structure of government levels, tax base, rates, exemptions, and deductions. From 2009, FB\&H implemented a new personal income tax by applying a flat tax rate of 10 percent. However, this simplified income taxation by replacing more than 60 cantonal taxes. This research empirically assesses the impact of selected labor market indicators on personal income taxation in FB\&H during the 2012-2016 period. By observing labor market indicators, the following variables are included in econometric modeling: income tax revenues, net wages, number of employed persons, consumer price indices and industrial production indices. In order to obtain empirical results, the VEC model and Johansen's cointegration approach are used.

Estimation results confirmed our hypothesis, which is that selected labor market indicators statistically significantly increase personal income taxation. In addition, the results of empirical research indicate that there is a statistically significant positive impact of average monthly wage and number of employed persons on personal income taxation in FB\&H in the long-run. Moreover, forecast error variance decomposition of the estimated error correction model is analyzed. Variance decomposition results point to the conclusion that, over time, real net wages and 
number of employed persons explain the considerable percent of the variation in personal income tax revenues. FB\&H implemented a flat tax rate of 10 percent on personal income in 2009 and some employed persons with very low income do not even pay personal income tax, and this explains a higher percentage of explained variation for wages. In order to decrease the high burden on labor, the implementation of reforms is necessary. This can be achieved with effective governance and general stable political environment. Data for a longer period and for other entities of B\&H (RS and Brčko District) are not available and is seen as the limitation of this research. For further research, the analysis of personal income tax reform in RS and Brčko District is recommended. It is also recommended to analyze the relationship between personal income taxation and economic growth in $\mathrm{B} \& \mathrm{H}$ in order to empirically assess the importance of personal income taxation for the overall economy.

\section{References}

1. Alesina, A., Rodrik, D. (1994), "Distributive politics and economic growth," Quarterly Journal of Economics, Vol. 109, No. 2, pp. 465-490.

2. Antić, D. (2013), "Multi-level fiscal system in Bosnia and Herzegovina: evolution and coping with economic crisis", Financial Theory and Practice, Vol. 37, No. 3, pp. 279-310.

3. Antonis, A., Pantelis, K., Lapatinas, A. (2015), "Income inequality and the tax structure: Evidence from developed and developing countries", Journal of Comparative Economics, Vol. 43, No. 1, pp. 138-154.

4. Bird, R. M., Zolt, E. M. (2005), "The limited role of the personal income tax in developing countries", Journal of Asian Economics, Vol. 16, No. 6, pp. 928-946.

5. Bovenberg, A. L. (2003), "Tax Policy and Labor Market Performance", CESifo working paper, No. 1035, Centre for Economic Studies, University of Munich, Munich.

6. Castro, G. A., Ramirez Camarillo, D. B. (2014), "Determinants of tax revenue in OECD countries over period 2001-2011", Contaduria y Administration, Vol. 59, No. 3, pp. 35-59.

7. Chu, K. (2000), "Income distribution and tax and government spending policies in developing countries", working paper, No. 214, UNU World Institute for Development Economic Research, Finland.

8. Diamond, P., Saez, E. (2011), "The case for a progressive tax: From basic research to policy recommendation", Journal of Economic Perspectives, Vol. 25, No. 4, pp. 165-190.

9. Enders, W. (2015), Applied Econometric Time Series. John Wiley \& Sons, London.

10. Federal Ministry of Finance of Federation of Bosnia and Herzegovina (2017), "Monthly reports on public revenues 2012-2016", available at: http://www.fmf.gov.ba/v2/stranica.php?idstranica=154\&idmeni=16\# (25 February 2018).

11. Federal Office of Statistics of Federation of Bosnia and Herzegovina (2017), Statistical Yearbook 2013-2017, Sarajevo.

12. Giammatteo, M. (2006), "Inequality in Transition countries: The Contributions of Market and Government Taxes and Transfers", LIS working paper, No. 443, Luxembourg Income Study, Luxembourg.

13. International Monetary Fund (2015), "Bosnia and Herzegovina-selected issues", available at: https://www.imf.org/external/pubs/ft/scr/2015/cr15299.pdf (06 March 2018).

14. Ivanitskaya, S., Tregub, I.V. (2013), "Mathematical model of income tax revenue on the UK example", available at:

http://www.freit.org/WorkingPapers/Papers/Development/FREIT550.pdf (20 February 2018).

15. Karabarbounis, L. (2011), "One dollar, one vote", Economic Journal, Vol. 121, No. 553, pp. 621-651.

16. Keane, M. P., Prasad, E. S. (2002), "Inequality, Transfers and Growth: New Evidence from the Economic Transition in Poland", The Review of Economics and Statistics, Vol. 84, No. 2, pp. 324-341. 
17. Koeninger, W., Leonardi, M., Nunziata, L. (2007), "Labor Market Institutions and Wage Inequality", Industrial and Labor Relations Review, Vol. 60, No. 3, pp. 340-356.

18. Kramer, Dž. (2016), Personal Income Tax Reform in the Federation of Bosnia and Herzegovina, Doctoral Dissertation, University of Ljubljana, Faculty of Economics, Ljubljana.

19. Lütkepohl, H. (2005), New Introduction to Multiple Time Series Analysis, Springer-Verlag, Berlin Heidelberg.

20. Lütkepohl, H. (2004), "Vector Autoregressive and Vector Error Correction Models", in Lütkepohl, H., Krätzig, M. (Eds.), Applied Time Series Econometrics Cambridge, University Press, pp. 86-158.

21. Maddala, G. S., Lahiri, K. (2009), Introduction to Econometrics, John Wiley \& Sons, England.

22. Milanovic, B. (2000), "The median-voter hypothesis, income inequality and income redistribution: an empirical test with the required data", European Journal of Political Economy, Vol. 16, No. 3, pp. 367-410.

23. Milanovic, B. (1999), "Explaining the increase in inequality during transition", Economics of Transition, Vol. 7, No. 2, pp. 299-341.

24. Mitra, P., Yemetsiv, R. (2006), "Increasing inequality in transition economies: is there more to come?", World Bank Policy Research working paper, No. 4007, World Bank, Washington D.C.

25. Nestić, D. (2002), "Ekonomske nejednakosti u Hrvatskoj 1973-1998" [Economic Inequalities in Croatia 1973-1998], Financial Theory and Pratice, Vol. 26, No. 3, pp. 596-613.

26. Obadić, A., Šimurina, N., Sonora, R. J. (2014), "The effects of tax policy and labour market institutions on income inequality", Zbornik radova Ekonomskog fakulteta Rijeka, Vol. 32, No. 1, pp. 121-140.

27. Palić, I., Dumičić, K., Grofelnik, B. (2017a), "Analysis of Personal Income Taxation Determinants in Croatia in Long Run: Evidence from Cointegration Analysis", Our Economy, Vol. 63, No. 3, pp. 12-18.

28. Palić, I. (2017), "The analysis of domestic Balassa-Samuelson effect in Croatia: Evidence from long run model", in: Zadnik Stirn, L., Kljajić Borštnar, M., Žerovnik, J., Drobne, S. (Eds.), Proceedings of the 14th International Symposium on Operational Research in Slovenia SOR'17, Bled, pp. 53-58.

29. Palić, I., Žmuk, B., Grofelnik, B. (2017b), "The long-run impact of personal income taxation on economic development: Evidence from Croatia", Croatian Review of Economic, Business and Social Statistics, Vol. 3, No. 1, pp. 35-44.

30. Paturot, D. (2017), "Taxing wages: how taxes affect the disposable income of workers and wage costs of employers in OECD countries", available at: http://oecdobserver.org/news/fullstory.php/aid/5916/Taxing_wages:_how_taxes_affect_t he disposable income_of_workers_and_wage_costs_of_employers_in_OECD_countries.ht ml (11 October 2018).

31. Pechman, J. A. (1987), "Tax Reform: Theory and Practice", Economic Perspectives, Vol. 1, No. 1, pp. 11-28.

32. Perotti, R. (1996), "Growth, income distribution, and democracy: What the data say", Journal of Economic Growth, Vol. 1, No. 2, pp. 149-187.

33. Rosen, H. S., Gayer, T. (2008), Public Finance, McGraw-Hill Irwin, United States of America.

34. Sahinagic, Dz., Bosnic, P. (2005), "Potential Revenue Impacts of the Proposed Personal Income Tax Law in the Federation of Bosnia and Herzegovina", available at: https://pdf.usaid.gov/pdf_docs/pnadd464.pdf (25 February 2018).

35. Sever, I., Drezgić, S. (2003), "Koncepcija i strategija socijalnih odnosa u hrvatskom društvu distribucija dohotka i imovine" [The concept and strategies of social relationships in Croatian society - income distribution and property], Economics, Vol. 10, No. 1, pp. 179201.

36. Šimurina, N., Barbić, D. (2017a), "Porezne promjene i dohodovne nejednakosti u Europskoj uniji tijekom financijske krize" [The Impact of Tax Changes on Income Inequalities in the EU during Financial Crisis], Revija za socijalnu politiku, Vol. 24, No. 2, pp. 123-142.

37. Šimurina, N., Barbić, D. (2017b), "Tax changes in the EU-13 during the recent financial crisis", in Wach, K., Knežević, B., Šimurina, N. (Eds.), Challenges for international business in Central and Eastern Europe, Cracow University of Economics, Krakow, pp. 139-151. 
38. Tax Administration of Federation of Bosnia and Herzegovina (2018), "Law on Personal Income Tax in Bosnia and Herzegovina", available at: http://www.pufbih.ba/v1/public/upload/zakoni/788f3-10 08-bs.pdf (10 October 2018).

39. United States Census Bureau (2017), "X-13ARIMA-SEATS Reference Manual, Time Series Research, Statistical Research Division", available at: http://www.census.gov/ts/X13as/docX13ASHTML.pdf (4 April, 2018)

40. Urban, I. (2006), "Progressivity of personal income tax in Croatia: Decomposition of tax base and rate effects", Financial Theory and Practice, Vol. 30, No. 3, pp. 207-231.

\section{About the authors}

Irena Palić is currently employed as Assistant Professor at the Department of Statistics, Faculty of Economics and Business, University of Zagreb. She graduated in 2008 at the Faculty of Economics and Business, University of Zagreb, majoring in Finance. During the study, she has been awarded the Dean's Award four times for great success and results achieved. Also, she received The City of Zagreb scholarship and the State Scholarship of the Ministry of Science, Education, and Sports. She post-graduated in Statistical Methods for Economic Analysis and Forecasting and gained a Ph.D. degree in Economics at Faculty of Economics and Business, University of Zagreb. Her main research fields are the application of statistics and econometrics in business, finance and economics, multivariate methods and dynamic stochastic general equilibrium models. She has published 39 scientific papers. As part of the Erasmus program for professional training in March 2014, she stayed at Wirtschaftsuniversitat in Vienna. The author can be contacted at ipalic@efzg.hr.

Sabina Hodžić, Ph.D., is an Assistant Professor and Head of the Department of Public Finance at the Faculty of Tourism and Hospitality Management, University of Rijeka (Croatia). Her main fields of research are public finance, current taxation issues, as well as local and regional development. She lectures on public finance and international taxation and is the author of several papers published in scientific journals. She is a member of the Network of Institute and Schools of Public Administration in Central and Eastern Europe (NISPACee) and a member of the International Fiscal Association of Bosnia and Herzegovina (IFA B\&H). The author can be contacted at sabinah@fthm.hr.

Ksenija Dumičić, Ph.D., has been Full Tenured Professor at Department of Statistics, University of Zagreb Faculty of Economics and Business, where she leads the statistical postgraduate program. She teaches statistical courses at the doctoral level in Croatia, Slovenia and Bosnia, and Herzegovina. She specialized at Institute for Social Research at the University of Michigan, focusing on survey sampling, SQC and business statistics. She led and participated in projects granted by Croatian Ministry of Science, World Bank, UNICEF, WHO, EU, etc. She has been President of Croatian Statistical Association, Leader of its Women in Statistics Section, one of Editors-in-Chief for Croatian Review of Economic, Business and Social Statistics. She has been the International Statistical Conference in Croatia (ISCCRO) general chair. She is the International Statistical Institute (ISI) Elected Member, contributing to its associations: IASS, IASE and WSC, member of Royal Statistical Society, American Statistical Association and American Society for Quality's Statistical Division. She published more than 180 publications. The author can be contacted at kdumicic@net.efzg.hr. 